The Door Swings In and Out: The Impact of Family Support and Country Stability on Women Entrepreneurs' Success in the Arab World

\author{
International Small Business Journal, Vol. 39, No. 7, 2021 \\ https://doi.org/10.1177/0266242620952356
}

\title{
Author Pre-Print
}

Dianne H. B. Welsh*

The University of North Carolina at Greensboro

\author{
Eugene Kaciak \\ Brock University \\ and \\ Kozminski University \\ Salime Mehtap \\ American University of Kuwait \\ Massimiliano M. Pellegrini \\ University of Rome 'Tor Vergata' \\ Andrea Caputo \\ University of Lincoln \\ and \\ University of Trento \\ Siddiga Ahmed \\ The University of North Carolina at Greensboro
}

*Corresponding author 


\title{
The Door Swings In and Out: The Impact of Family Support and Country Stability on Women Entrepreneurs' Success in the Arab World
}

\begin{abstract}
Women-owned businesses represent a significant segment of the contemporary economy upon a global basis. However, women entrepreneurs still experience more obstacles than men depending on cultural context; for example, research on the Arab world concerning the interaction between women entrepreneurs and their families remains under-developed. Consequently, we ground our study upon an enhanced framework of agency theory, which includes family altruism. We examined the relationships between business-family interface (BFI) enrichment components and the performance of firms headed by female entrepreneurs women in Jordan and Sudan. Specifically, we investigated if and how the country level of political and social stability moderates these relationships. The findings suggest that the relationship between the family-related objective factor (family financial support) and the performance of firms headed by female entrepreneurs is not affected by the country's political and social stability context. Conversely, the family-related subjective factor (family moral support) is affected by this context. Our study bridges the gap in contextual studies on the Arab world concerning the success of women-owned businesses and confirms how institutional elements affect business in addition to family-related matters. Implications for future research and public policy are discussed.
\end{abstract}

Keywords: Arab world, country political stability, country social stability, family financial support, family moral support, Jordan, Sudan, women entrepreneurs

\section{Introduction}

Women-owned businesses cover the globe and represent a significant segment of the world economy (ILO, 2014). Yet, female entrepreneurship is still curbed by feminine gender role expectations, societal and business discrimination, and/or differential treatment (Brush et al., 2009; Cetindamar et al., 2012). Despite this very real-world problem (https://www.gemconsortium.org/report/49860), there is only limited research that considers the factors affecting the performance of firms headed by female entrepreneurs through the lens of country-specific peculiarities (Mari et al., 2016; Simon-Moya et al., 2014). For example, only a 
few studies looked at country characteristics and how they relate to female entrepreneurs' behaviours and outcomes (Daniele and Geys, 2016; Pathak et al., 2013; Welsh et al., 2016; 2018a). Similarly, in closer social environments, families and their regional and cultural embeddedness may play a role (Gupta et al., 2011). These factors should be reflected in any approach to women's entrepreneurship. Entrepreneurship scholars have called for the investigation of how institutional environments influence entrepreneurial judgment and behaviours (Foss et al., 2019). Therefore, we posit the following research question: in the case of women entrepreneurs, does family support, either tangible or intangible, affect firm level performances differently in relation to external institutional conditions? We focus our attention on the Arab world, where the institutional environment at any level can result in particularly harsh conditions for females in business (Essers and Benschop, 2009). Therefore, the saliency of this context is quite fertile for contributing to the investigation of the cognitive and normative impacts of institutions on entrepreneurial decision making and behaviour (Foss et al., 2019).

To answer this question by tangling the nexus that may occur between a female entrepreneur and her family, we use the work-family interface (WFI) paradigm (Greenhaus and Allen, 2011; Jennings and McDougald, 2007), simply readapted to the case in which "the work" to balance out is an entrepreneurial one. Recently, WFI has garnered increased attention, including a global tencountry study (Korabik et al., 2017), a monograph on the intersection between gender and workfamily domains (Mills, 2015), the first comprehensive overview of the work-family interface in sub-Saharan Africa (Mokomane, 2014), and a review of 72 articles (Michael-Tsabari et al., 2020). In this case, the proper term for the paradigm becomes business-family interface (BFI) (Hsu et al., 2016). BFI covers the overall spectrum of effects that family and business may reciprocally exert on each other.

To investigate the influence of country context on women's entrepreneurship, we use the country's level of political and social stability as a possible moderator of the links between the BFI elements and firm performance. We position our study in the framework of agency theory, through the lens of familial altruism (Schulze et al., 2003a, 2003b), supplemented with the institutional logic perspective (Fama, 1980; North, 1990). Political stability is intimately tied with social stability and the role of women (Bowen et al., 2015; Hudson et al., 2009, 2012, 2015) and; thus, we consider this will significantly impact female entrepreneurship. 
We use the binary logistic regression as the method of analysis of cross-sectional data collected in two countries, Jordan and Sudan, which share similar cultural and religious core beliefs but different levels of political and social/institutional stability. We demonstrate that (contrary to what we expected), the political and social stability context does not influence the relationships between family-related objective factor, exemplified by family financial support, and performance of firms headed by female entrepreneurs in the two countries. However, we find that family-related subjective factor, such as the perceived extent of family moral support, is related differently to firm performance, depending on the extent of the country's political and social stability.

The paper's contribution is twofold. First, our study "bridges" the gap of contextual studies in a new under-explored domain (e.g., the Arab world) showing how women's entrepreneurship in developing countries cannot be seriously studied without considering the family environment (Caputo et al., 2016; 2017; Cetindamar et al., 2012; Essers and Benschop, 2009; Mehtap et al., 2017; Ramadani and Hoy, 2015). Second, the study reinforces the assumption that social/institutional elements also have a major impact on the business as well as family-related matters (Gray and Finley-Hervey, 2005; Gupta et al., 2011; Petrolo et al., 2018; Stough et al., 2015).

The paper is organized as follows. First, a conceptual framework is defined, and the hypotheses are developed. Subsequently, the methodology and results are presented and discussed. Finally, we conclude with limitations and recommendations.

\section{Theoretical background}

We conduct our research in the context of interactions between a female entrepreneur and her family. Work and family are intertwined areas of life for most entrepreneurs, but they may be especially interconnected for female business owners (Hodges et al., 2015; Loscocco and Bird, 2012; Shelton, 2006). Research on the relationships between these two domains typically invokes the work-family interface (WFI) literature (Greenhaus and Allen, 2011; Jennings and McDougald, 2007). In our study, we use the term business-family interface or BFI, in line with Hsu et al. (2016). BFI is spanned across two dimensions: enrichment (i.e., a positive connection between business and family domains), and interference (i.e., a conflict between the two areas). For entrepreneurial success, the importance of family dynamics has been largely acknowledged (Aldrich and Cliff, 2003; Heck and Trent, 1999; Shelton, 2006). The family may represent an asset or a liability, providing either enrichment (instrumental and/or affective) or interference for the entrepreneur. 
In this study, we focus only on the enrichment dimension of the BFI. Enrichment, according to Eddleston and Powell (2012) and Powell and Eddleston (2013), is the positive experience of being involved simultaneously in the family and business domain. An instrumental dimension of enrichment (Cetindamar et al., 2012; King et al., 1995) is the ability to transfer skills and behaviours acquired or nurtured in the family (e.g., multitasking or being physically supportive) to the business or solid support mobilizing resources from one domain to another. Examples of such support would be a family member who assumes a major share of household duties to allow the woman entrepreneur to dedicate more time to work and to the business (Ahl, 2006; Shelton, 2006), giving expert advice in running the business (Eddleston and Powell, 2012; Kolvereid et al., 1993; Renzulli et al., 2000), working for the business with little or no pay (Alsos et al., 2014; Jennings and Brush, 2013), or lending money to the business (Essers and Benschop, 2009). An affective dimension of enrichment is a positive emotional state created in the family environment which can positively affect the mental attitude towards the business (Jennings and Brush, 2013). It is well-established in the literature that family support (instrumental and/or affective) may positively impact women's ability to be successful entrepreneurs (Eddleston and Powell, 2012; King et al., 1995; Kolvereid et al., 1993; Powell and Eddleston, 2013).

Because relations between families and businesses may involve various agency-type relationships, which are strongly affected by the level of intra-familial altruism (Karra et al., 2006), we ground our study in the theory of agency and altruism (Schulze et al., 2003a, 2003b). We note that agency theory is conventionally employed to explain the effects of relationships among organizations such as owners and managers, in family firms in general (Westhead and Howorth, 2007), and specifically in relation to women in family firms (Campopiano et al., 2017). However, instances where a business venture involves any kind of family ties (e.g., family investing in a business of one of its members) may also be considered a variant of the "agency" agreement (Gomez-Mejia et al., 2001). Family involvement may be represented as a series of agency-type contracts spread across the spectrum from pure familial altruism to pure economic rationality (Steier, 2003). We adopt the agency perspective through the lens of altruism to explain the relationship between the involvement of a family and its support and the performance of a firm headed by one of its members - a woman entrepreneur.

There is much debate in the literature about whether familial altruistic behaviour helps or impedes business performance and under what circumstances (Karra et al., 2006). Miller et al. 
(2017) offer insights into this dilemma by showing that it is the institutional logic at the regional level that may have a vital impact on the governance arrangements and financial performance of family firms. We use a similar approach and extend our analysis, through the institutional logic lens, to a higher level of the country context (i.e., the political and social stability) to investigate the relations between the enrichment sub-dimensions of the BFI and firm performance.

\section{Country political and social stability context}

In addition to the family-business nexus, it also is important to understand the significance of the general context for studies on women's entrepreneurship in general and specifically in Arab countries (Dana and Dana, 2005). Because a conservative culture and a patriarchal approach are deeply socially-embedded in this part of the world (Caputo, 2018; Dana, 2000; Petrolo et al., 2018), female entrepreneurs here face stronger barriers compared to their colleagues elsewhere (Dana et al., 2018; Kolvereid et al., 1993). While Islam per se is not a constraining factor for women's participation in economic activity, social customs and tribal traditions may inhibit entrepreneurial attitudes towards women in the Arab world. Society beliefs still encourage a woman to find a husband and start a family rather than focus on a career and economic empowerment (Anggadwita et al., 2015; Essers and Benschop, 2009; Hakki and Somach, 2012; Ramadani et al., 2013).

However, a patriarchal approach perpetrated through male dominance and inequality may also lead to the formation of two strong tribal and clan-based alternative structures of power (Collins, 2004; Hudson et al., 2009; Gellner, 1990). According to this assumption, these powerful groups may impair the full democratization of a country leading to political and social fragility (Bowen et al., 2015; Hudson et al., 2012). We want to focus on developing countries, particularly in the Arab world, where the culture tends to be generally conservative and patriarchal (Cetindamar et al., 2012; Petrolo et al., 2018), to determine if a more evident institutional force is present. Different levels of political and social stability may contribute to different psychological pressures on female entrepreneurs (Essers and Benschop, 2009). For example, in some Arab countries, a woman may need a male family member as an agent to run her business. Whether this condition is required in countries, such as Saudi Arabia, or is not a legal requirement, as in Jordan and Sudan, can impact the business. This "forced" male aegis may limit sensibly the female entrepreneur's ability to perform autonomously (Welsh et al., 2018b) and depress her spirit (Welsh et al., 2018b). Yet coupled with this as a common element in Arab countries is a major level of political and social instability. This situation reduces hurdles that must still be tackled by any entrepreneur, 
regardless of gender, worsening the situation. This situation is another reason why, for an Arab woman, the family environment is a crucial element to turn attention to (Gray and Finley-Hervey, 2005). Beyond this, there are also strong calls (e.g., Fahed-Sreih and Djoundourian, 2006; Ramadani and Hoy, 2015) for contextualization studies that encompass both the family business and entrepreneurship fields (e.g., Cetindamar et al., 2012; Welter, 2011) concerning regional factors (Gupta et al., 2011; Welsh and Raven, 2006).

As mentioned earlier, we investigate the performance of firms headed by female entrepreneurs in Jordan and Sudan in relation to family financial and moral support (Noguera et al., 2015) while assuming a possible moderating influence of the country political and social stability level on such links (Welsh et al., 2018a). The explanatory variables that we consider are part of the businessfamily interface (BFI) (Jennings and McDougald, 2007; Hsu et al., 2016). Family financial and moral support are two enrichment sub-dimensions of the BFI. Specifically, family financial support constitutes an instrumental (objective, tangible) component of the BFI, while family moral support is an affective (subjective, intangible) BFI element.

\section{Family financial support and firm performance}

As discussed, family financial support is typically considered the instrumental component of the BFI enrichment dimension (Hsu et al., 2016). Instrumental support may be exercised through family organizational assistance with running the business (Arregle et al., 2007; Eddleston and Powell, 2012), including financial support (Akehurst et al., 2012; Kim and Gao, 2013). Specifically, family members may provide the entrepreneur with the use of family finances or help in obtaining external funding sources (Aldrich and Cliff, 2003; Anderson et al., 2005; Dyer and Handler, 1994), thus enhancing her entrepreneurial performance. Other researchers also reported that such family support can positively influence firm performance (Verheul et al., 2006; Chang et al., 2009; Powell and Eddleston, 2013), while lack of family support can have negative effects (Sharma, 2008).

Considering the country context, the possible lack of instrumental support from families in the investigated countries, Jordan and Sudan, is one of the greatest impediments to women entrepreneurs' experience (Mehtap et al. 2017), thus affecting their business performance (Tlaiss, 2014). This lack of family support is firmly rooted in avoidance of uncertainty, the masculine nature of the society, and collectivism, three of the elements of Hofstede's taxonomy of cultural values (Hofstede, 2001) in Arab countries (Tlaiss, 2014). For a woman entrepreneur to be able to 
launch and grow her business venture in such adverse conditions, family financial support may be valuable and indispensable (Cetindamar et al., 2012). Thus, it seems that any presence of family instrumental, tangible, support should improve women's entrepreneurial performance in these countries.

As mentioned, we are particularly interested in determining how a level of a country's political and social stability affects the link between a family's decision to offer financial support (in any form) to one of its members, and the resulting performance of the firm headed by the family member. We posit that the context of the Arab world, in general, should make a difference as preliminary assessed by Welsh et al. (2018a), mainly when the regional factors of political and social stability are considered.

We draw on the theory of agency and altruism (Schulze et al., 2003a, 2003b), supplemented with the institutional economics perspective (Fama, 1980; North, 1990), to hypothesize the moderating influence of the country context (the level of political and social stability) on the relationship between the family financial investment in their relative's firm and its performance. In instances where a business venture involves any kind of family ties, it represents a variant of the agency contract (Steier, 2003). We argue that in countries plagued by institutional voids (e.g., a lack of institutional norms and regulations) (Chakrabarty, 2009); weak rule of law (Estrin and Mickiewicz, 2011), monitoring and exercising contracts (including between family members), may be difficult. These impediments may dishearten family members from taking any formal financial position in their relative's business dealings, which may lead to weaker economic performance of her firm. Even if the family members would like to help their relative-entrepreneur, they may be discouraged from doing so by the uncertainties created by institutional voids in political and social systems that, in turn, may ultimately also affect the economic system. Family members may be more encouraged to get involved financially and/organizationally in their relative's firm when they do not fear a loss of their investment. This fear may be alleviated by the perception of a stable legal and economic country system. Conversely, the country's political and social instability may push family involvement along the earlier mentioned spectrum of the agency-type contracts away from familial altruism in the direction of more economic rationality (Steier, 2003). In such cases, family altruism may not be a decisive factor in whether to get involved. Instead, family members will look at the purely economic side of their business dealings 
with another family member and decide whether to invest. Such decisions may result in a positive outcome in countries that are more stable rather than in countries plagued by institutional voids.

Finally, instrumental enrichment (financial support received from the family), in a more stable country with a more developed economic system, could be only one of the possible alternatives to finance a nascent business. While family remains vital in terms of support, in a more structured economic system, women entrepreneurs may leverage such support to accrue other resources and to take advantage of external opportunities for financing their businesses (Welsh et al., 2018b). This situation would also imply that women entrepreneurship in a more politically and socially stable country is less of a necessity. Still, rather women are pulled into the business by suitable opportunities.

For all those reasons combined, we expect that country-level of political and social stability affects the link between family financial support and performance of firms headed by women entrepreneurs:

H1. Country-level of political and social stability will moderate the relationship between family financial support and performance of women-headed firms, such that higher family financial support will be more likely to lead to higher performance of women-headed firms in a country with a higher level of stability than in a country with lower levels.

\section{Family moral support and firm performance}

The emotional support of entrepreneurs has been well-recognized in the literature as necessary (Hoang and Antoncic, 2003; Liao and Welsch, 2005; Prasad et al., 2013). Family members tend to exhibit altruistic and nurturing behaviours (Steier, 2003), such as mentoring and guidance (Arregle et al., 2007), that can positively contribute to the business startup and successful management activities in business endeavours. Women entrepreneurs particularly benefit from family-to-business affective support (Powell and Eddleston, 2013) to a greater degree than their male counterparts. Family members' moral support can be psychological assistance to a female entrepreneur in dealing with her business problems (Eddleston and Powell, 2012; Ramadani et al., 2013).

Family moral support is part of family social capital, a kind of capital that is characterized by family relationships (Cetindamar et al., 2012; Davidsson and Honig, 2003). Family moral support gives a woman entrepreneur confidence that she can successfully manage her family-business responsibilities. A positive relationship between the family affective support and performance of 
firms headed by female entrepreneurs was found in China (Welsh et al., 2017a) and Turkey (Welsh et al., 2018a).

Family moral support belongs to a different category of support compared to financial support - it does not involve any money or any other substantial, organizational effort from the family. The family's risk is minimal if any. Stemming from our previous discussion that led to the development of Hypothesis 1, we reiterate that in less politically and socially stable (and, thus, usually poorer) countries, families may not be able to offer financial support to their entrepreneurial relatives, even if they would like to. Due to institutional voids, their exposure to risks involved would be too high to encourage any altruistic financial involvement. However, the family members in such countries are very likely to possess collectivistic orientations that may foster loyalty, interdependence, and commitment to the family's long-term prosperity, even if the business is not a family business. They may remain closer to the altruistic end of the spectrum of agency-type contracts and offer (albeit only) affective support.

Finally, we also note that in the Arab world, there is a strongly patriarchal and paternalist approach, especially towards female family members (Caputo, 2018; Mehtap et al., 2019; Petrolo et al., 2018). This situation implies that where women are more emancipated and where the business world is more open to the presence of women as evident in stable countries (i.e., Jordan), strong emotional support from the family may be perceived by the female entrepreneur as a lack of confidence in her abilities. In this case, the family's emotional support could ironically be even detrimental.

We posit that country level of political stability moderates the relationship between family moral support and women entrepreneurs' performance:

H2. Country-level of political and social stability will moderate the relationship between family moral support and performance of women-headed firms, such that higher family moral support will be more likely to lead to higher performance of women-headed firms in a country with a lower level of stability than in a country with higher levels.

Fig. 1 illustrates the research model.

\section{Insert Figure 1 about here}

\section{Method}

Data collection and sample 
We compare Jordan and Sudan, which are considered to share similar beliefs and traditions, mainly based on the precepts of Islam, the Arabic language, and common cultural backgrounds. There are nevertheless significant differences between countries in the region (Welsh et al., 2018a), which sharply differ in other ways, such as resource endowment, economic frailty, and the specific interest of our study, political and social stability. As the body of research on women's entrepreneurship in developing contexts is steadily growing, more attention is needed to understand these phenomena in the predominantly traditional, patriarchal, and tribal societies of the Arab world (Caputo et al., 2017; Hattab, 2012). Social and cultural barriers often restrict women's participation in the formal workforce, thus limiting their ability to contribute to the economic prosperity of the region and their personal development (Al-Salem and Speece, 2017; Kaciak and Welsh, 2020; Mehtap et al., 2019; Welsh et al., 2017b). Today, Arab women's economic participation remains the lowest in the world and constitutes only twenty-five percent of the workforce (ILO, 2014). As a result, many governments in the Arab world are encouraging entrepreneurial activity, not only as a means of promoting economic development and creating jobs but also as a means of circumventing traditional labour market barriers and employment taboos for women (Welsh et al., 2017b).

Jordan is an upper-middle-income country and ranks 142 out of 194 countries on the Political Stability Index (The Global Economy, 2017). Despite being shaken by changes that began with the Arab Spring in 2011, it remains one of the few stable countries in a region that is generally torn by war. For many years, Jordan has opened its borders to Arab nationals fleeing conflict in their homelands and is a haven for refugees and displaced individuals, most recently Syrians. The Human Development Index for the country stands at 86 (UNDP, 2016a). According to the World Bank (2016), Jordan ranks 119 on the Ease of Starting a Business Index. On average, twelve days are needed to complete all the necessary paperwork to launch a business. In 2015, Jordan had a Gender Inequality Index of 0.478 and a ranking of 111 out of 188 countries (UNDP, 2016a).

Sudan has a mid-range human development index of 165 (UNDP, 2017) and, according to the World Bank (2016) classification, is a lower-middle-income country. Since declaring independence in 1956, Sudan has been plagued by civil wars. The Political Stability Index ranks Sudan at 186 out of 194 countries (The Global Economy, 2017). In general, entrepreneurship is not encouraged as a profession. There are a limited number of entrepreneurship programs, scarce technical training, and weak national planning (Rahman et al., 2019). According to the World 
Bank (2016), Sudan ranks 164 on the Ease of Starting a Business Index, with an average of 36 days needed to complete all necessary paperwork to launch a business. Sudan has a Gender Inequality Index of 0.575 and ranks 140 out of 188 countries in 2015 (UNDP, 2016b).

By focusing on Jordan and Sudan, we introduce a country context and investigate its importance to women's entrepreneurial processes in the Arab region. Specifically, because religion and culture are similar in both countries, we control indirectly for these important socio-cultural factors known to affect entrepreneurial outcomes (Griffiths et al., 2013). In return, we expect to identify a possible impact of the country's level of political and social stability on the processes pertinent to women's entrepreneurship in the two countries.

In both countries, Jordan and Sudan, the same, self-administered questionnaire, adapted from Hisrich et al. (2006), was utilized. This questionnaire was initially developed by Hisrich and Brush (1982, 1984, 1985), with subsequent modifications (Hisrich et al., 2006; Lerner et al., 1997).

It is challenging to collect/access data in Jordan and even more so in Sudan, due to the cultural context and deficiencies in official data collection on women entrepreneurs in both countries (Kharouf et al., 2007; Khattab et al., 2017). Even in instances where some form of data has been collected, the validity of the data collection methods can be questioned by researchers (Al-Zoubi, 2014).

It was difficult to track down a list of female entrepreneurs in Jordan, even though the help of various official organizations were elicited. All we were able to obtain was the number of female registered businesses in Amman from the Chamber of Commerce. In Jordan, both versions of the questionnaire were initially posted on Qualtrics, which is a web-based tool for creating and conducting online surveys. Personal contacts of one of the researchers were sent an invitation to respond to the questionnaire, and they were also asked to forward the email to other female entrepreneurs in their networks.

In Jordan, a total of 120 questionnaires were distributed in early 2016. A total of 116 female entrepreneurs responded (usable paper questionnaires were 106, and a further ten came from online responses).

More than half of respondents are below 40 years of age (66\%) and have at least a college degree (84\%). More than half (62\%) are married. Their businesses are mature (72\% are at least three years old, while $48 \%$ have been in business for at least five years). Women have a leadership role in their business (88\%) and the majority ownership (70\%). The firms are unevenly split 
between family businesses (25\%) and non-family businesses (75\%). The businesses were started either mostly alone (58\%), with family members $(27 \%)$, or with non-relatives $(15 \%)$. The profile of the respondents seems to be similar to respondent profiles of a study conducted in 2007 by the Center of Women Studies at the University of Jordan. The study looked at 444 Jordanian female business owners and found that in terms of education, more than 65 percent held higher degrees (college or bachelor's degree), 74 percent were between the ages of 25-44 years of age, and that amongst those who were shareholders in a business, over 70 percent worked with a family member or members.

As to Sudan, there is no systematic, officially collected data on women entrepreneurs in this country (El Khider, 2012; Musa, 2012). The negative culture further hampers any attempts at data collection towards research and data collection (Khattab et al., 2017). Therefore, other authors have resorted to convenience sampling and have tried to do their best to ensure that the sample was representative of female businesses of varying sizes, industries and geographic areas (El Khider, 2012; Khattab et al., 2017). Data collection took place in north Sudan from October December of 2011 using field research methods. In total, 103 usable questionnaires were received.

More than half of respondents are above 40 years of age $(70 \%)$. Less than half $(45 \%)$ have at least a college degree. More than half (69\%) are married. Their businesses are mature (73\% are at least three years old, while $66 \%$ have been in business for at least five years). Women do have a principal role in their business (99\%); however, only 19\% enjoy the majority ownership. The firms are very unevenly split between family businesses (15\%) and non-family businesses (85\%). The businesses were started either mostly alone (81\%), with family members (7\%), or with nonrelatives $(12 \%)$. The profile of the respondents seems to have similar characteristics with studies that have looked at women entrepreneurs in Sudan. These studies profile the respondents to be mostly older, primarily educated and illiterate (Badri, 2013; El Khider, 2012; Khattab et al., 2017). Measures

\section{Dependent variable}

Firm performance (PERF) is the dependent variable assessed using the respondent's current annual (self-reported) business income. Despite obvious subjectivity, self-reported performance measures are reliable and highly correlated with objective data (Cruz et al., 2012). Business income (or revenue) is among the most frequently used and validated indicators of firm financial performance (Dyer et al., 2012). All respondents were presented with the same five annual income 
brackets from which they could choose one that best reflected their business income. For each country, the brackets were adjusted so that the middle (third) bracket contained the average yearly salary. The income selections were then aggregated into two categories, coded (1) when the respondent's annual business income was selected from any of the three highest income categories (high business performance group), and (0) when the first two income brackets were selected (low business performance group). Other studies (Cetindamar et al., 2012; Diaz-Garcia and Brush, 2012) also used an income-related categorical measure of firm performance, though with more than two categories.

Firm performance, as well as the other variables that were initially measured at the interval level, were significantly skewed. Therefore, we decided to downgrade them to the nominal level. Admittedly, we lost some information, but we avoided having to deal with strongly skewed measures, which could distort the results.

\section{Independent variables}

Family financial support (FFS). Access to financial capital is particularly important for womenowned businesses (Akehurst et al., 2012; Bardasi et al., 2011; Iakovleva et al., 2013; Jennings and Brush, 2013; Shelton, 2006; Sullivan and Meek, 2012), especially during the startup phase. It provides a woman entrepreneur with more flexibility and control to focus on the management and growth of her business (Akehurst et al., 2012; Cetindamar et al., 2012; Tlaiss, 2014). This variable was coded as (1) if a woman entrepreneur started the business borrowing from her family and (0) when she financed the startup with her own savings, with money borrowed from non-relatives, and/or banks (Cruz et al., 2012).

Family moral support (FMS). Family moral support is often closely related to the level of business-family balance (Rehman and Roomi, 2012; Shelton, 2006). It has been considered an important factor in shaping women's entrepreneurial processes (Chang et al., 2009; 2012). We measured moral support from the family at two levels: (1) perceived support from the family member (spouse, parent, child, sibling, and/or relative), and (0) perceived lack of such support.

The country political and social stability context (STB). This variable (the moderator) was coded as (1) to indicate a higher level of overall stability (Jordan), and as (0) to indicate a lower level of such stability (Sudan).

Control variables 
We controlled for additional covariates to eliminate their possible influence on the relationships between the predictors and the dependent variable. Thus, we attempted to minimize the confounding (omitted variable) bias. Entrepreneur's age (ENTR_AGE) has an important influence on entry into entrepreneurship and subsequent stages of the business venture (Pathak et al., 2013). In this study, ENTR_AGE was categorised as (1) if the entrepreneur was 40 and older and as (0) otherwise. The benchmark of 40 years, separating mature from younger women entrepreneurs, has been used in other studies (Mas-Tur et al., 2015). Firm age (FIRM_AGE) was categorized as (1) when the firm was at least five years in operation and (0) otherwise. Firm size (FIRM_SIZE) was coded as 1 for a firm with at least one full-time employee (not counting an owner) and 0 when the firm did not employ anyone except the owner (solo-entrepreneur). We also controlled whether the firm was a family business or not (family business ownership, FBO). The relationship between family business ownership and firm performance has been researched extensively in the literature. However, empirical findings have not been conclusive (Arosa et al., 2010). Some results of the studies suggest that family business ownership positively influences firm performance (Welsh et al., 2018a, 2017c), other empirical outcomes indicate either a negative impact of family organizational involvement on profitability (Arosa et al., 2010) or no relationship at all (Welsh et al., 2014). No consensus has been established regarding the definition of a family firm (Howorth et al., 2010). This study used Westhead's (1997) definition that an owner's "perception" is one of the elements that most closely captures the family business concept. Therefore, the respondents were asked to make their own judgment to determine whether their business was a "family business" in responding to the survey items. This variable was also measured at two levels coded as (1) if participants defined their business as family-oriented, and as (0) when the participants indicated otherwise.

Because our study uses self-reported data collected in a cross-sectional survey, there is a legitimate concern about the effects of the common method variance (CMV), which may artificially inflate relationships among variables (Simmering et al., 2015; Spector and Brannick, 2009). To control for method variance problems, we used the correlational marker technique (Lindell and Whitney, 2001). A key requirement of this technique is that a questionnaire includes a so-called marker variable. The details of the technique are presented later. A marker variable is supposed to be theoretically unrelated to substantive dependent and independent variables of a model. In our study, we also followed an additional recommendation from Williams et al. (2010) 
that a marker variable should be selected based on a theoretical rationale explaining how well it taps into one or more of the sources of bias (Podsakoff et al., 2003). This situation can occur in the measurement context for given substantive variables being examined. Based on the above considerations, we decided to include in our questionnaire a variable that measured a respondent's interest in joining women entrepreneurs' networking groups (JOIN_NETW): (1) if no interest was indicated and (0) when a respondent answered this question positively. We are unaware of any conceptual models or empirical research linking interest in joining women entrepreneurs' networking groups with firm performance or with other family-business interface types of substantive variables included in our study. Thus, we assume that our marker variable may be theoretically unrelated to these variables. Furthermore, we think that it could be the case that our marker variable taps into some of the biases described by Podsakoff et al. (2003), such as social desirability, consistency motifs, and transient mood states. Finally, we note that our marker variable was in the questionnaire in close vicinity to the dependent variable to address both CMV and serial-position effects (Lindell and Whitney, 2001).

\section{Moderated multiple linear regressions}

Since our dependent variable was dichotomous, we chose binary logistic regression (logit) for our analyses. The equation used was:

$\mathrm{PERF}=\alpha+\beta_{1} \mathrm{ENTR} \_\mathrm{AGE}+\beta_{2} \mathrm{BUS} \_\mathrm{AGE}+\beta_{3} \mathrm{BUS} \_\mathrm{SIZE}+\beta_{4} \mathrm{FBO}+\beta_{5} \mathrm{FFS}+\beta_{6} \mathrm{FMS}+\beta_{7} \mathrm{STB}$ $+\beta_{8} \mathrm{FFS} \times \mathrm{STB}+\beta_{9} \mathrm{FMS} \times \mathrm{STB}+\varepsilon$, where $\mathrm{PERF}=1$ if business performance is above average and 0 if it is below, ENTR_AGE $=1$ if the entrepreneur's age is at least 40 years and 0 otherwise, FIRM_AGE $=1$ when the firm was at least five years in operation and 0 otherwise, FIRM_SIZE $=1$ for a firm with at least one full-time employee and 0 when the firm did not employ anyone except the owner, FBO $=1$ if family business ownership was declared and 0 if not, FFS $=1$ if the business was started with money borrowed from the family and 0 when it was financed with own savings and/or with money borrowed from non-relatives/banks, FMS $=1$ if moral support from the family was acknowledged and 0 when not, STB $=1$ if the country's level of political and social stability is higher (Jordan) and 0 when it is lower (Sudan). In line with other research (e.g., Rudolph et al., 2014), the model reported here is specified without the marker variable.

We tested the hypotheses based on the combined sample of both Jordanian and Sudanese respondents. Descriptive statistics for the pooled sample are presented in Table 1.

Insert Table 1 about here 
The dependent variable was measured against the control and, sequentially, independent variables, the moderator, and the products of the independent variables and the moderator (Table 2).

\section{Insert Table 2 about here}

\section{Common Method Variance}

As mentioned earlier, collecting data from self-reported questionnaires at one point in time can lead to common method bias (Podsakoff et al., 2003). We used the correlational marker technique (Lindell and Whitney, 2001) to assess this issue.

The correlational marker technique calls for selecting the smallest observed correlation between the marker variable and one of the substantive variables (which is 0.009 , the correlation coefficient between JOIN_NETW and FFS; Table 1). Lindell and Whitney (2001) propose calculating the partial correlations between the dependent variable and each of the predictors controlling for CMV. The selected smallest coefficient serves as an estimate of the amount of method variance. The following equation is used to remove shared variance between the marker and other variables:

$$
\mathrm{r}_{\mathrm{YXi} . \mathrm{M}}=\left(\mathrm{r}_{\mathrm{YXi}}-\mathrm{r}_{\mathrm{s}}\right) /\left(\left(1-\mathrm{r}_{\mathrm{S}}\right)\right.
$$

where $r_{Y X i . M}$ is the partial correlation between $Y$ (the dependent variable) and $\mathrm{X}_{\mathrm{i}}$ (the independent variables) controlling for CMV, $\mathrm{r}_{\mathrm{YXi}}$ is the observed correlation between $\mathrm{Y}$ and $\mathrm{X}_{\mathrm{i}}$ possibly contaminated by $\mathrm{CMV}$, and $\mathrm{r}_{\mathrm{s}}$ is the smallest observed correlation between the marker variable and one of the substantive variables with which it is expected to be theoretically unrelated. Thus, this approach partials out the same amount of method variance at the construct level from all relationships in the data set. The resulting "corrected" correlations should be closer approximations to true relationships than the uncorrected correlations (Richardson et al., 2009). If a significant correlation becomes nonsignificant after correction, common method bias is assumed to have been in effect. The statistical significance of the "corrected" correlations is tested with the t-test statistic (Lindell and Whitney, 2001):

$$
\mathrm{t}_{\alpha / 2, \mathrm{~N}-3}=\mathrm{rYXi.M}_{\mathrm{M}} / \sqrt{ }\left(1-\mathrm{r}^{2} \mathrm{YXi.M}\right) /(\mathrm{N}-3)
$$

The correlation coefficients $\mathrm{r}_{Y X i}$, the partial correlation coefficients $\mathrm{r}_{Y X i . M}$, and their corresponding t-test statistics are displayed in the last three rows of Table 1. Table 1 shows that the correlation for FMS is not significant even before the CMV adjustment is applied. However, the correlation for FFS with the dependent variable remains statistically significant even when $\mathrm{CMV}$ is controlled. Thus, one can conclude that this correlation cannot reasonably be accounted 
for by CMV and that the variable FFS still retains its "practical significance in terms of a meaningful amount of variance explained" (Lindell and Whitney, 2001: 119).

To minimise the common-method biases inherent in surveys, we also undertook several ex-ante remedies, as suggested in the literature (Podsakoff et al., 2003). Specifically, we made sure that the wording of the items offered their clear meanings to the survey respondents. The Arabic version of the questionnaire was shown to linguistic experts who recommended some re-wording to reflect the local cultural conditions of the two countries.

Furthermore, to reduce the potential bias due to common scale formats, we used various scale formats. The questionnaire included a mixture of dichotomous, multiple-choice, open-ended, and rank-order items to assess the nature of women's entrepreneurship in each country. Finally, it is worth noting that our approach to the CMV threat allows us to minimize the effect of social desirability bias (Podsakoff et al., 2003), which refers to the tendency of some respondents to provide their answers based more on their perception of social acceptability than their true feelings. This situation gives us more confidence that our findings, although based on surveys conducted in various countries, are based on equivalent samples.

\section{Missing Observations}

Due to the method and the location of data collection, we experienced some missing observations. For most of the variables, the percentage of missing observations was between 7-9 percent. Two variables had this percentage somewhat higher - family financial support (11.9\%) and firm performance (15.1\%). Because of this fairly considerable percentage of missing data, we used pairwise deletion of missing data rather than, for example, list-wise (total) deletion. Of course, the issue with pairwise deletion is that different correlations are based on different subsets of cases and, therefore, parameter estimates may be biased. The estimation of standard errors is also problematic. However, Graham (2009) suggests that these biases may be small if the correlation matrix is positive definite. This situation can be tested by checking whether the last eigenvalue obtained in the principal component analysis of the data is positive. If this is the case, the last eigenvalue will have variance, thus adding new information over and above the other factors; the matrix is then positive definite. The principal component analysis of the data produced all positive eigenvalues. The last one contributed $5.42 \%$ to the total variance, which suggested that employing the pairwise deletion of the missing observations may be an acceptable approach.

\section{Results}




\section{Hypothesis testing}

Standard tests for multicollinearity were conducted on the explanatory variables. The highest VIF score was 1.25 , and the greatest condition index was 6.59 . Values for both statistics were well below the common rules of thumb of 10 and 15-30 for each test. Therefore, multicollinearity was not a threat. To address the possibility that the error term does not have constant variance, heteroscedasticity-robust standard errors were estimated (White, 1980). Overall, all models are significant (all p-values for the $\chi^{2}$ statistic are below 0.05 ), meaning that they are significantly different from the model with the constant only.

Family financial support. The interaction (Model 2) between family financial support and the country's level of stability is not related to firm performance, contrary to hypothesis H1.

Family moral support. The interaction (Model 3) between family moral support and the country's level of stability is negatively related to firm performance in support of hypothesis $\mathrm{H} 2$.

A moderation plot of the significant interaction between the independent variable (family moral support) and the moderator provides further support and explanation of the interaction effect proposed in Hypothesis 2 (See Figure 2). Concerning the control variables, age and size of the firm are positively related to firm performance, as expected, across Models 2-4.

\section{Insert Figure 2 about here}

\section{Discussion}

We examined the relationships between BFI enrichment components and the performance of firms headed by female entrepreneurs in Jordan and Sudan.

Specifically, we investigated if and how the country level of political and social stability moderates these relationships. The findings suggest that the relationship between the familyrelated objective factor, such as family financial support, and performance of firms headed by female entrepreneurs in the two countries, is not affected by the country political and social stability context. However, the family-related subjective factor, exemplified in our study by the perceived extent of family moral support, is affected by this context.

Our moderation results are interesting given recent findings by Welsh et al. (2018a) on the moderating effect of the country level of economic development experienced in Morocco and Turkey. Specifically, this study found significant the country economic context moderation effect on the relationship between family financial support and firm performance. Family financial support is more beneficial to female entrepreneurs in less economically developed countries, such 
as Morocco, compared to more economically advanced economies, like Turkey. In our study, no significant moderation effect of the country political and social context was found for this kind of relationship. Therefore, we suggest that studies investigating the role of "the country context" should be precise in terms of defining "context" (e.g., "contextualizing contexts") (Welter et al., 2016). Our findings compared to those of Welsh et al. (2018a) suggest that various country-level contexts may have different effects on female entrepreneurship and the role of their family.

Also, this result confirms that the objective intervention of the family in a female business does not predict performance when the political and social stability of a country is factored in. Thus, even though family support is vital for female entrepreneurs in a developing country (Cetindamar et al., 2012), the country stability does not regulate various possible agency-based contracts (Steier, 2003) that may occur between the family and its female entrepreneur members.

When family financial support was substituted with family moral support in the Welsh et al. (2018a) study, these researchers reported that family moral support was associated with a better firm performance among Turkish female entrepreneurs compared to their Moroccan counterparts. As explained earlier, in the current Jordan vs. Sudan study, we found that the positive relationship between family moral support and firm performance is stronger in less politically stable countries. We note different effects of the country context on the same relationships among the same variables in a research model depending on whether the context is the country's economic development or political and social stability. Our findings indicate that political and social context affects female entrepreneurship differently from what could be said for the country's economy (Bowen et al., 2015; Collins, 2004; Gellner, 1990; Hudson et al., 2009; 2012).

\section{Conclusion}

Our study makes several contributions, both to the family business and female entrepreneurship literature. Our research bridges the gap of contextual studies in new under-explored domains (Gupta et al., 2011; Simon-Moya et al., 2014), particularly the Arab world, where the role of women in business is a key and fundamental issue (Daniele and Geys, 2016; Welsh et al., 2016, 2018a). Given the highly conservative and patriarchal nature of the region, the prevalence of gender stereotypes and the importance of familial bonds and kinship are major factors to consider. Our study confirms how institutional elements also have a major impact on business and familyrelated matters, often putting different pressures on women and the performance of their firms. We emphasise an essential role of various contextual factors in shaping the BFI dimensions at the 
country (macro)-, family (meso)-, and personal (micro)-level. Our study theoretically contributes to linking the BFI dimensions to the performance of female-run firms and offers support for how social and institutional elements can have a significant impact on the female-run business as well as the family-related matters. This conclusion is evident in the fact that the relationship between the BFI dimension of family moral support and firm performance is moderated by the level of political and social stability, confirming that support is perceived differently according to contextual dimensions (Foss et al., 2019).

Thus, any steps towards encouraging female entrepreneurship will require serious efforts to breakdown socio-cultural taboos and stigmas surrounding women in business that exist in both countries (Foss et al., 2018; Hudson et al., 2009; Gellner, 1990). Policies that promote womenowned businesses and support them are crucial in breaking down barriers that exist (Foss et al., 2018; Mehtap et al., 2017). According to Haifa Abu Ghazaleh, Assistant Secretary-General, Head of Media and Communication, League of Arab States (Jordan), "Women are often portrayed as victims of the conflict. They are, of course, targeted for rape, become widows, suffer most from the decay of social sectors, and are amongst the most vulnerable victims in war and conflict situations. However, they are also often the ones who trigger peace mechanisms and take on new economic roles, often as heads of household [...], there needs to be an investment in the role of women in economic and social development. Promoting equality in education would play a pivotal role in bridging the gender gap between men and women, as would advocating for women's rights so more women can pave the way for a successful future in the Middle East. This result can be achieved through the support of initiatives that seek primarily to improve women's social and legal rights in the Arab world" (Wilson Center, 2017). The ability of Arab countries to move forward politically and socially depends on their ability to enable all their citizens to be successful, including women entrepreneurs (Bowen et al., 2015; Hudson et al., 2012, 2015).

\section{Practical implications, limitations, and future research}

From a practical point of view, our study offers insights. Information about programs and agencies that support female entrepreneurs should be better disseminated amongst the public so that women know where to turn to if they have a business idea, need funding, or further business training. For example, many Jordanian female entrepreneurs are engaged in informal entrepreneurial activities - usually from home-based businesses - as it allows them to balance the work-life interface and fulfill their other aspirations. 
Regional policies that consider contextual differences could be effective based on our results (for a review of women's entrepreneurship policy research, see Foss et al., 2018). Policies should focus on solutions to the intangible effects of family moral support. Childcare and eldercare subsidies, as well as subsidizing assistance with other household duties for women-owned businesses, would be a measurable step forward. Regional women's entrepreneurship conferences with training sessions in finance, marketing, regulations, legal issues, among others, could be supported by lending institutions and universities. Regional awards that are widely advertised and promoted emphasizing successful women entrepreneurs would be one step to address the stigma of women in business. Awards may raise family moral support by developing a positive view of women working for the family.

Overall, economic growth in both Sudan and Jordan has not translated into equivalent human development improvements. There are significant disparities between urban and rural areas in both countries. Both Jordan and Sudan need to address the problem of overcrowding in the public sectors, high levels of unemployment. They need to find stepwise solutions to tackle poverty, especially outside of their capitals. A significant challenge in both contexts is the restructuring of the economy in ways that promote non-reliance on the government sector. The ability to create new opportunities for women and their businesses will allow both countries to capitalize on highly educated women entrepreneurs and untapped potential.

This study has limitations, including sample size and convenience sampling. However, as explained in the Method section, collecting data from these countries is challenging (Khattab et al., 2017). The second limitation is that although the study insured anonymous responses and responsible research safeguards, due to the strong masculine orientation of the environments, respondents may have been hesitant to answer the questions due to problems with officials, police, tax consequences, family reprisals, or being stereotyped due to the masculine orientation of both countries. The third limitation is that we were forced to handle missing observations through the pairwise deletion with all its well-known deficiencies. The list-wise deletion was not an option because of the loss of cases due to missing data would have been more than 5\% (Roth, 1994; Graham, 2009). A more "modern" method of missing data analysis, such as multiple imputations procedures (Graham, 2009; Rubin, 1987), was not an option either due to the categorical nature of the variables with missing data. In this case, imputation under the normal model may not work properly, and some ad hoc fixes must be used (Graham, 2009). Finally, our study was limited to 
more urban areas. Data collection is extremely difficult for rural areas. Family business researchers should consider joint projects with anthropologists, sociologists, and agricultural researchers to better secure data in rural areas. Also, the researchers called for public sector entities to make available gender-disaggregated data.

Concerning general practical implications, entrepreneurship education could be an area of development and future research. The divide between educated and uneducated women needs to be addressed. This divide is especially evident in rural vs. urban areas. We suggest that entrepreneurship education could start at an early age and continued in high schools, universities and beyond. Focus on open access to females must be made a priority in any entrepreneurship education program, and research should be conducted that focuses on the effectiveness of entrepreneurship education at various levels. Innovation education with entrepreneurship education, particularly in the STEM fields, would catapult businesses to be developed that produce higher-paying employment. Addressing the stigmas women face should be part of the curriculum that both sexes are exposed to with the intent of gradually changing the existing societal and cultural norms of future generations. Longitudinal studies need to be conducted that measure the effect of entrepreneurship education, and at what stage in the education process, it should be introduced to measure if/when the entrepreneurial propensity of students increases.

Future studies could examine further if and how the country level context makes a difference between Arab and developing countries on a larger scale with more countries involved. Studies could be conducted to include more Arab countries and compare differences. Comparative studies that build on the same theoretical framework in other empirical settings is encouraged that might lead to a better understanding of the country-level context on women entrepreneurs. The impact of the family on women-owned businesses needs further exploration. Longitudinal studies need to be undertaken and considered. For example, longitudinal studies comparing women-owned businesses could be conducted across countries past the startup stage. Funding for research and widespread dissemination of results by governments are integral to these efforts. Case studies and life histories need to be conducted (Henry et al., 2016). Future research might also attempt to examine the influence of the multi-level contextual factors on the BFI dimensions by performing multi-level mediation analysis (Zhang et al., 2009).

\section{References}


Ahl H (2006) Why research on women entrepreneurs needs new directions. Entrepreneurship Theory \& Practice, 30(5): 595-621.

Akehurst G, Simarro E and Mas-Tur A (2012) Women entrepreneurship in small service firms: Motivations, barriers, and performance. The Service Industries Journal, 32(15): 2489-2505.

Aldrich H and Cliff J (2003) The pervasive effects of family on entrepreneurship: Toward a family embeddedness perspective. Journal of Business Venturing, 18(5): 573-596.

Al-Salem A and Speece M (2017) Women in leadership in Kuwait: A research agenda. Gender in Management: An International Journal, 32(2): 141-162.

Alsos G, Carter S and Ljunggren E (2014) Kinship and business: How entrepreneurial households facilitate business growth. Entrepreneurship \& Regional Development, 26(1-2): 97-122.

Al-Zoubi A (2014) The effect of sex (gender) on the success of business women in the business environment on marketing in Jordan: An empirical study. British Journal of Marketing Studies, 2(7): 45-59.

Anderson A, Jack S and Dodd S (2005) The role of family members in entrepreneurial networks: Beyond the boundaries of the family firm. Family Business Review, 18(2): 135-154.

Anggadwita, G, Mulyaningsih, HD, Ramadani, V and Arwiyah, MY (2015) Women entrepreneurship in Islamic perspective: A driver for social change. International Journal of Business and Globalisation, 15(3): 389-404.

A/Rahman W, Alshiehk L, Mubashar N, Alsaeed M and Yassin M. (2019) Global Entrepreneurship Monitor: Sudan National Report 2018/2019. Global Entrepreneurship Monitor. Available at: www.gemconsortuim.org (accessed 15 December 2019). 
Arosa B, Iturralde T and Maseda A (2010) Outsiders on the board of directors and firm performance: Evidence from Spanish non-listed family firms. Journal of Family Business Strategy, 1(4): 236245.

Arregle J, Hitt M, Sirmon D, et al. (2007) The development of organizational social capital: Attributes of family firms. Journal of Management Studies, 44(1): 73-95.

Badri AY (2013) The role of micro-credit system for empowering poor women. Developing Country Studies, 3(5): 71-83.

Bardasi E, Sabarwal S and Terrell K (2011) How do female entrepreneurs perform? Evidence from three developing regions. Small Business Economics, 37(4): 417-441.

Brush C, De Bruin A and Welter F (2009) A gender-aware framework for women's entrepreneurship. International Journal of Gender and Entrepreneurship, 1(1): 8-24.

Bowen D, Hudson V and Nielsen P (2015) State fragility and structural gender inequality in family law: An empirical investigation. Laws, 4(4): 654-672.

Campopiano G, De Massis A, Rinaldi F, et al. (2017) Women's involvement in family firms: Progress and challenges for future research. Journal of Family Business Strategy, 8(4): 200-212.

Caputo A (2018) Religious motivation, nepotism and conflict management in Jordan. International Journal of Conflict Management, 29(2): 146-166.

Caputo A, De Vita L, Mari M, et al. (2017) Female entrepreneurship in developing contexts: Characteristics, challenges and dynamics. In: Ratten V, Dana LP and Ramadani V (eds) Women entrepreneurship in family business. Routledge: London.

Caputo A, Mehtap S, Pellegrini MM, et al. (2016) Supporting opportunities for female entrepreneurs in Jordan. International Journal of Entrepreneurship and Small Business, 
27(2-3): 384-409.

Cetindamar D, Gupta V, Karadeniz E, et al. (2012) What the numbers tell: The impact of human, family and financial capital on women and men's entry into entrepreneurship in Turkey. Entrepreneurship \& Regional Development, 24(1-2): 29-51.

Chakrabarty S (2009) The influence of national culture and institutional voids on family ownership of large firms: A country level empirical study. Journal of International Management, 15(1): 3245.

Chang E, Memili E, Chrisman J, et al. (2009) Family social capital, venture preparedness, and startup decisions. Family Business Review, 22(3): 279-292.

Chang E, Memili E, Chrisman J, et al. (2012) What can drive successful entrepreneurial firms? An analysis of the Inc. 500 companies. Journal of Small Business Strategy, 22(2): 27-49.

Collins K (2004) The logic of clan politics: Evidence from the Central Asian trajectories. World Politics, 56(2): 24-61.

Cruz C, Justo R and De Castro J (2012) Does family employment enhance MSEs performance? Integrating socioemotional wealth and family embeddedness perspectives. Journal of Business Venturing, 27(1): 62-76.

Dana LP (2000) Economies of the Eastern Mediterranean Region. Singapore: World Scientific.

Dana LP and Dana TE (2005) Expanding the scope of methodologies used in entrepreneurship research. International Journal of Entrepreneurship and Small Business, 2(1): 79-88.

Dana LP, Ratten V and Honyenuga BQ (eds) (2018) African Entrepreneurship. London: Palgrave. 
Daniele G and Geys B (2016) Family ties and socio-economic outcomes in high vs low income countries. The Journal of Development Studies, 52(6): 813-823.

Davidsson P and Honig B (2003) The role of social and human capital among nascent entrepreneurs. Journal of Business Venturing, 18(3): 301-331.

Diaz-Garcia M and Brush C (2012) Gender and business ownership: Questioning 'what' and 'why.' International Journal of Entrepreneurial Behaviour \& Research, 18(1): 4-27.

Dyer G, Dyer J and Gardner R (2012) Should my spouse be my partner? Preliminary evidence from the panel study of income dynamics. Family Business Review, 26(1): 68-80.

Dyer G and Handler W (1994) Entrepreneurship and family business: Exploring the connections. Entrepreneurship Theory and Practice, 19(1): 71-83.

Eddleston K and Powell G (2012) Nurturing entrepreneurs' work-family balance: A gendered perspective. Entrepreneurship Theory and Practice, 36(3): 513-541.

El Khider A (2012) Emerging women entrepreneurs in Sudan: Individual characteristics, obstacles and empowerment. ICBE-RF Research Report, 33(12).

Essers C and Benschop Y (2009) Muslim businesswomen doing boundary work: The negotiation of Islam, gender and ethnicity within entrepreneurial contexts. Human Relations, 62(3): 403-423.

Estrin S and Mickiewicz T (2011) Institutions and female entrepreneurship. Small Business Economics, 37(4): 397-415.

Fahed-Sreih J and Djoundourian S (2006) Determinants of longevity and success in Lebanese family businesses: An exploratory study. Family Business Review, 19(3): 225-234. 
Fama E (1980) Agency problems and the theory of the firm. Journal of Political Economy, 88(2): 288-307.

Foss L, Henry C, Ahl H, et al. (2018) Women's entrepreneurship policy research: A 30-year review of the evidence. Small Business Economics, 53(2): 409-429.

Foss, N. J., Klein, P. G., \& Bjørnskov, C. (2019). The context of entrepreneurial judgment: organizations, markets, and institutions. Journal of Management Studies, 56(6), 1197-1213.

Gellner E (1990) Tribalism and the state in the Middle East. In: Khoury, PS and Kostiner, J (eds) Tribes and States Formation in the Middle East. Los Angeles: University of California Press, pp. 109-126.

Gomez-Mejia R, Nuñez-Nickel M and Gutierrez I (2001) The role of family ties in agency contracts. The Academy of Management Journal, 44(1): 81-95.

Graham W (2009) Missing data analysis: Making it work in the real world. Annual Review of Psychology, 60: 549-576. DOI: 10.1146/annurev.psych.58.110405.085530.

Gray K and Finley-Hervey F (2005) Women and entrepreneurship in Morocco: Debunking stereotypes and discerning strategies. International Entrepreneurship and Management Journal, 1(2): 203-217.

Greenhaus J and Allen T (2011) Work-family balance: A review and extension of the literature. In: Quick J and Tetrick L (eds) Handbook of Occupational Health Psychology. Washington, DC: American Psychological Association, pp. 165-183.

Griffiths M, Gundry L and Kickul J (2013) The socio-political, economic, and cultural determinants of social entrepreneurship activity: An empirical examination. Journal of Small Business and Enterprise Development, 20(2): 341-357. 
Gupta V, Levenburg N, Moore L, et al. (2011) The spirit of family business: A comparative analysis of Anglo, Germanic and Nordic Nations. International Journal of Cross-Cultural Management, 11(2): 133-151.

Hakki H and Somach S (2012) Gender analysis and assessment. Report no. 11-01-596, March. Washington, DC: United States Agency for International Development. Retrieved from https://jordankmportal.com/system/.../Gender_Analysis_and_Assessment_-_2012.pdf

Hattab H (2012) Towards understanding female entrepreneurship in Middle Eastern and North African countries. Education, Business and Society: Contemporary Middle Eastern Issues, 5(3): 171-186.

Heck R and Trent E (1999) The prevalence of family business from a household sample. Family Business Review, 12(3): 209-219.

Henry C and Foss L (2016) Gender and entrepreneurship research: A review of methodological approaches. International Small Business Journal, 34(3): 217-241.

Hisrich R, Bowser K and Smarsh L (2006) Women entrepreneurs in the Ukraine. International Journal of Entrepreneurship and Small Business, 3(2): 207-221.

Hisrich R and Brush C (1982) The woman entrepreneurs as a reflection of type of business. In: Hornaday, JA, Timmons, JA and Vesper, KH (eds) Frontiers of Entrepreneurship Research, pp. 54-67. Boston, MA: Babson College.

Hisrich R and Brush C (1984) The woman entrepreneur: Management skills and business problems. Journal of Small Business Management, 22(1): 30-37.

Hisrich R and Brush C (1985) Women and minority entrepreneurs: A comparative analysis. In: Hornaday JA, Shils EB, Timmons JA, et al. (eds) Frontiers of Entrepreneurship Research, pp. 566-587. Boston, MA: Babson College. 
Hoang H and Antoncic B (2003) Network-based research in entrepreneurship: A critical review. Journal of Business Venturing, 18(2): 165-187.

Hodges N, Watchravesringkan K, Yurchisin J, et al. (2015) Women and apparel entrepreneurship. International Journal of Gender and Entrepreneurship, 7(2): 191-213.

Hofstede G (2001) Culture's Consequences: Comparing Values, Behaviors, Institutions, and Organizations across Nations. 2nd edn. Thousand Oaks, CA: SAGE Publications.

Howorth C, Rose M and Hamilton E (2010) Family firm diversity and development: An introduction. International Small Business Journal, 28(5): 437-451.

Hsu D, Wiklund J, Anderson S and Coffey B (2016) Entrepreneurial exit intentions and the businessfamily interface. Journal of Business Venturing, 31(6): 613-627.

Hudson V, Caprioli M, Ballif-Spanvill B, et al. (2009). The heart of the matter: The security of women and the security of states. International Security, 33(3): 7-45.

Hudson V, Bowen D and Nielsen P (2015) Clan governance and state stability: The relationship between female subordination and political order. American Political Science Review, 109(3): $535-555$.

Hudson V, Caprioli M, Emmett C, et al. (2012) Sex and World Peace. New York: Columbia University Press.

Iakovleva T, Solesvik M and Trifilova A (2013) Financial availability and government support for women entrepreneurs in transitional economies: Cases of Russia and Ukraine. Journal of Small Business and Enterprise Development, 20(2): 314-340. 
ILO (2014) Labour Inspection, Gender Equality and Non-Discrimination in the Arab States: Guide Book. Geneva, Switzerland: International Labour Organisation.

Jennings J and Brush C (2013) Research on women entrepreneurs: Challenges to (and from) the broader entrepreneurship literature? The Academy of Management Annals, 7(1): 663-715.

Jennings J and McDougald M (2007) Work-family interface experiences and coping strategies: Implications for entrepreneurship research and practice. Academy of Management Review, 32(3): 747-760.

Kaciak E. and Welsh DHB (2020) Women entrepreneurs and work-life interface: The impact of sustainable economies on success. Journal of Business Research, 112(C): 281-290. Epub ahead of print 1 February 2020. DOI: 10.1016/j.jbusres.2019.11.073.

Karra N, Tracey P and Phillips N (2006) Altruism and agency in the family firm: Exploring the role of family, kinship, and ethnicity. Entrepreneurship Theory \& Practice, 29(5): 861-877.

Kharouf A, Dababneh A and Akhal RK (2007) Women business owners in Jordan: Characteristics, contributions and challenges. The Center of Arab Women for Training and Research \& The International Finance Corporation (Gender Entrepreneurship Markets). Available at: https://www.ifc.org/wps/wcm/connect/650116fc-17a4-486b-b80a$368303 \mathrm{fa} 3 \mathrm{dbd} / \mathrm{Jordan} \% 2 \mathrm{Breport}$.pdf?MOD=AJPERES\&CACHEID=ROOTWORKSPACE650116fc-17a4-486b-b80a-368303fa3dbd-jqeuuep (accessed 2 September 2019)

Khattab I, Ahmed S and Mohmedahmed AMS (2017) Determinants of business entrepreneurship success in Sudan. Journal of Entrepreneurship and Organization Management, 6: 1-5. DOI: 10.4172/2169-026X.1000218.

Kim Y and Gao F (2013) Does family involvement increase business performance? Family- longevity goals' moderating role in Chinese family firms. Journal of Business Research, 66(2): 265-274. 
King L, Mattimore L, King D, et al. (1995) Family support inventory for workers: A new measure of perceived social support from family members. Journal of Organizational Behavior, 16(3): 235258.

Kolvereid L, Shane S and Westhead P (1993) Is it equally difficult for female entrepreneurs to start businesses in all countries? Journal of Small Business Management, 31(4): 43-51.

Korabik K, Aycan Z and Ayman R (eds) (2017) The Work-Family Interface in Global Context. New York: Routledge/Taylor \& Francis Group.

Lerner M, Brush C and Hisrich R (1997) Israeli women entrepreneurs: An examination of factors affecting performance. Journal of Business Venturing, 12(4): 315-339.

Liao J and Welsch H (2005) Roles of social capital in venture creation: Key dimensions and research implications. Journal of Small Business Management, 43(4): 345-362.

Lindell K and Whitney J (2001) Accounting for common method variance in cross-sectional research designs. Journal of Applied Psychology, 86(1): 114-121.

Loscocco K and Bird S (2012) Gendered paths: Why women lag behind men in small business success. Work and Occupations, 39(2): 183-219.

Mari M, Poggesi S and De Vita L (2016) Family embeddedness and business performance: Evidence from women-owned firms. Management Decision, 54(2): 476-500.

Mas-Tur A, Pinazo P, Tur-Porcar A, et al. (2015) What to avoid to succeed as an entrepreneur? Journal of Business Research, 68(11): 2279-2284.

Mehtap S, Pellegrini MM, Caputo A, et al. (2017) Entrepreneurial intentions of young women in the Arab world: Socio-cultural and educational barriers. International Journal of Entrepreneurial Behavior \& Research, 23(6): 880-902. 
Mehtap S, Ozmenekse L and Caputo A (2019) I'm a stay at home businesswoman: An insight into informal entrepreneurship in Jordan. Journal of Entrepreneurship in Emerging Economies, 11(1): 44-65.

Michael-Tsabari N, Houshmand M, Strike VM, et al. (2020) Uncovering implicit assumptions: Reviewing the work-family interface in family business and offering opportunities for future research. Family Business Review, 33(1): 64-89.

Miller D, Le Breton-Miller I, Amore M, et al. (2017) Institutional logic, family firm governance and performance. Journal of Business Venturing, 32(6): 674-693.

Mills M (ed) (2015) Gender and the Work-Family Experience: An Intersection of two Domains. Springer.

Mokomane Z (ed) (2014) Work-Family Interface in Sub-Saharan Africa: Challenges and Responses. London: Springer International Publishing.

Musa, EA (2012) Emerging women entrepreneurs in Sudan: Individual characteristics, obstacles and empowerment. ICBE-RF Research Report, 33(12), July.

Noguera M, Alvarez C, Merigo J, et al. (2015) Determinants of female entrepreneurship in Spain: An institutional approach. Computational and Mathematical Organization Theory, 21(4): 341-355.

North D (1990). Institutions, Institutional Change and Economic Performance. Cambridge, UK: Cambridge University Press.

Pathak S, Goltz S and Buche W (2013) Influences of gendered institutions on women's entry into entrepreneurship. International Journal of Entrepreneurial Behaviour \& Research, 19(5): 478502. 
Petrolo D, Pellegrini MM and Abukhalaf Y (2018) Family firms in the Arab world: Culture influences on socioemotional wealth. International Journal of Transition and Innovation Systems, 6(2):128145.

Podsakoff P, MacKenzie S, Lee JY and Podsakoff, NP (2003) Common method biases in behavioral research: A critical review of the literature and recommended remedies. Journal of Applied Psychology, 88(5): 879-903.

Powell G and Eddleston K (2013) Linking family-to-business enrichment and support to entrepreneurial success: Do female and male entrepreneurs experience different outcomes? Journal of Business Venturing, 28(2): 261-280.

Prasad V, Naidu G, Murthy B, et al. (2013) Women entrepreneurs and business venture growth: An examination of the influence of human and social capital resources in an Indian context. Journal of Small Business and Entrepreneurship, 26(4): 341-364.

Ramadani V, Gërguri S, Dana LP, et al. (2013) Women entrepreneurs in the Republic of Macedonia: Waiting for directions. International Journal of Entrepreneurship and Small Business, 19(1): 95121.

Ramadani V and Hoy F (2015). Context and uniqueness of family businesses. In: Dana LP and Ramadani V (eds) Family Businesses in Transition Economies. Zurich, Switzerland: Springer International Publishing, pp. 9-37.

Rehman S and Roomi M (2012) Gender and work-life balance: A phenomenological study of women entrepreneurs in Pakistan. Journal of Small Business and Enterprise Development, 19(2): 209-228.

Renzulli L, Aldrich H and Moody J (2000) Family matters: Gender, networks, and entrepreneurial outcomes. Social Forces, 79(2): 523-546. 
Richardson H, Simmering M and Sturman M (2009). A tale of three perspectives: Examining post hoc statistical techniques for detection and correction of common method variance. Organizational Research Methods, 12(4): 762-800.

Roth L (1994) Missing data: A conceptual review for applied psychologists. Personnel Psychology, 47(3): 537-56,

Rubin D B (1987) Multiple Imputation for Nonresponse in Surveys. New York: John Wiley \& Sons.

Rudolph W, Michel S, Harari B et al. (2014) Perceived social support and work-family conflict: A comparison of Hispanic immigrants and non-immigrants. Cross Cultural Management, 21(3): 306-325.

Schulze S, Lubatkin H and Dino N (2003a) Exploring the agency consequences of ownership dispersion among the directors of private family firms. The Academy of Management Journal, 46(2): 179-194.

Schulze S, Lubatkin H and Dino N (2003b) Toward a theory of agency and altruism in family firms. Journal of Business Venturing, 18(4): 473-490.

Sharma P (2008) Commentary: Familiness: Capital stocks and flows between family and business. Entrepreneurship Theory and Practice, 32(6): 971-977.

Shelton L (2006) Female entrepreneurs, work-family conflict, and venture performance: New insights into the work-family interface. Journal of Small Business Management, 44(2): 285-297.

Simmering M, Fuller C, Richardson H, et al. (2015) Marker variable choice, reporting, and interpretation in the detection of common method variance: A review and demonstration. Organizational Research Methods, 18(3): 473-511.

Simon-Moya V, Revuelto-Taboada L and Guerrero R (2014) Institutional and economic drivers of entrepreneurship: An international perspective. Journal of Business Research, 67(5): 715-721. 
Spector P and Brannick M (2009) Common method variance or measurement bias? The problem and possible solutions. In: Buchanan D and Bryman A (eds) The Sage Handbook of Organizational Research Methods. Thousand Oaks, CA: Sage Publications Ltd, pp. 346-362.

Steier L (2003) Variants of agency contracts in family-financed ventures as a continuum of familial altruistic and market rationalities. Journal of Business Venturing, 18(5): 597-618.

Stough R, Welter F, Block J, et al. (2015) Family business and regional science: "Bridging the gap." Journal of Family Business Strategy, 6(4): 208-218.

Sullivan D and Meek W (2012) Gender and entrepreneurship: A review and process model. Journal of Managerial Psychology, 27(5): 428-458.

The Global Economy (2017) Political stability-country rankings.

Available at: http://www.theglobaleconomy.com/rankings/wb_political_stability/ (accessed 2 January 2020).

Tlaiss H (2014) Women's entrepreneurship, barriers and culture: Insights from the United Arab Emirates. Journal of Entrepreneurship, 23(2): 289-320.

UNDP (2016a) Human development reports 2016: Jordan.

Available at: http://hdr.undp.org/en/countries/profiles/JOR (accessed 4 January 2020).

UNDP (2016b) Human development reports 2016: Sudan.

Available at: http://hdr.undp.org/en/countries/profiles/SDN (accessed 4 January 2020).

UNDP (2017) About Sudan.

Available at: http://www.sd.undp.org/content/sudan/en/home/countryinfo.html (accessed 5 January 2020). 
Verheul I, Van Stel A and Thurik R (2006) Explaining female and male entrepreneurship at the country level. Entrepreneurship \& Regional Development, 18(2): 151-183.

Welsh DHB, Kaciak E, Memili E, et al. (2018a) Business-family interface and the performance of women entrepreneurs: The moderating effect of economic development. International Journal of Emerging Markets, 13(2): 330-349.

Welsh DHB, Kaciak E, Memili E, et al. (2017a) Work-family balance and marketing capabilities as determinants of Chinese women entrepreneurs' firm performance. Journal of Global Marketing, 30(3): 174-191.

Welsh DHB, Kaciak E and Minialai C (2017b) The influence of perceived management skills and perceived gender discrimination in launch decisions by women entrepreneurs. International Entrepreneurship and Management Journal, 13(1): 1-33.

Welsh DHB, Kaciak E and Shamah R (2018b) Determinants of women entrepreneurs' firm performance in a hostile environment. Journal of Business Research, 88(C): 481-491.

Welsh DHB, Kaciak E and Thongpapanl N (2016) Influence of stages of economic development on women entrepreneurs' startups. Journal of Business Research, 69(11): 4933-4940.

Welsh DHB, Kaciak E, Trimi S et al. (2017c) Women entrepreneurs and family firm heterogeneity: Evidence from an emerging economy. Group Decision \& Negotiation, 27(3): 445-465.

Welsh DHB, Kim G, Memili E et al. (2014) The influence of family moral support and personal problems on firm performance: The case of Korean women entrepreneurs. Journal of Developmental Entrepreneurship, 19(3): 1-17.

Welsh DHB and Raven P (2006) Family business in the Middle East: An exploratory study of retail management in Kuwait and Lebanon. Family Business Review, 19(1): 29-48. 
Welter F (2011) Contextualizing entrepreneurship-conceptual challenges and ways forward. Entrepreneurship Theory and Practice, 35(1): 165-184.

Welter F, Gartner WB and Wright M (2016) The context of contextualizing contexts. In: Welter F and Gartner WB (eds) A Research Agenda for Entrepreneurship and Context. Cheltenham: Edward Elgar Publishing, pp. 1-15.

Westhead P and Howorth C (2007) 'Types' of private family firms: An exploratory conceptual and empirical analysis. Entrepreneurship and Regional Development, 19(5): 405-431.

Westhead P (1997) Ambitions, 'external' environment and strategic factor differences between family and non-family companies. Entrepreneurship and Regional Development, 9(2): 127-157.

White H (1980) A heteroskedasticity-consistent covariance matrix estimator and a direct test for heteroskedasticity. Econometrica, 48(4): 817-830.

Williams J, Hartman N and Cavazotte F (2010) Method variance and marker variables: A review and comprehensive CFA marker technique. Organizational Research Methods, 13(3): 477-514.

Wilson Center (2017) Women driving positive change in the Middle East. Available at: http://www. wilsoncenter.org/publication/women-driving-positive-change-the-middle-east (accessed 15 December 2019).

World Bank (2016) Jordan overview. Available at: http://www.worldbank.org/en/country/jordan/overview (accessed 10 November 2019).

Zhang Z, Zyphur MJ and Preacher KJ (2009) Testing multi-level mediation using hierarchical linear models. Organizational Research Methods, 12(4): 695-719. 


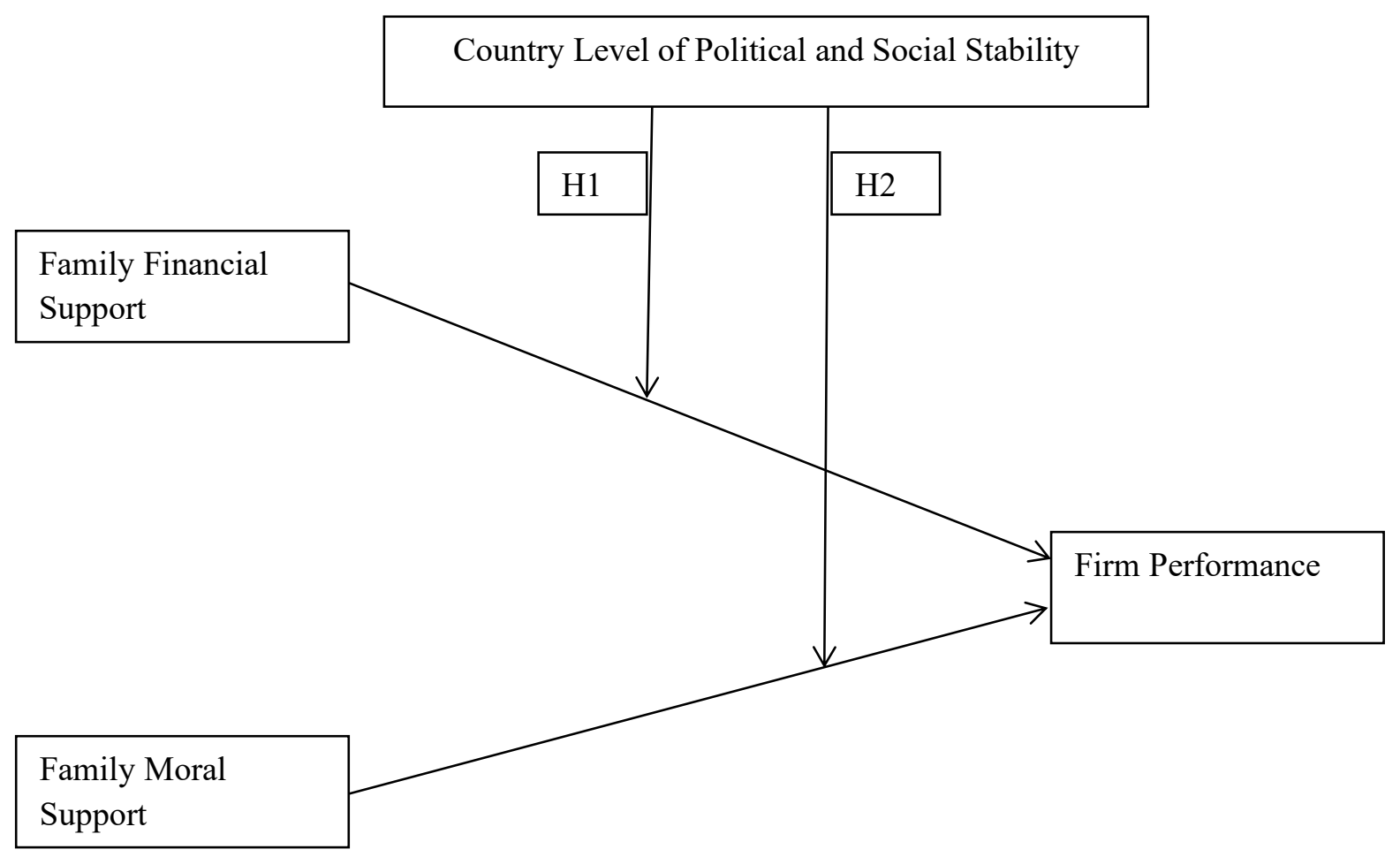

Fig. 1. The research model 


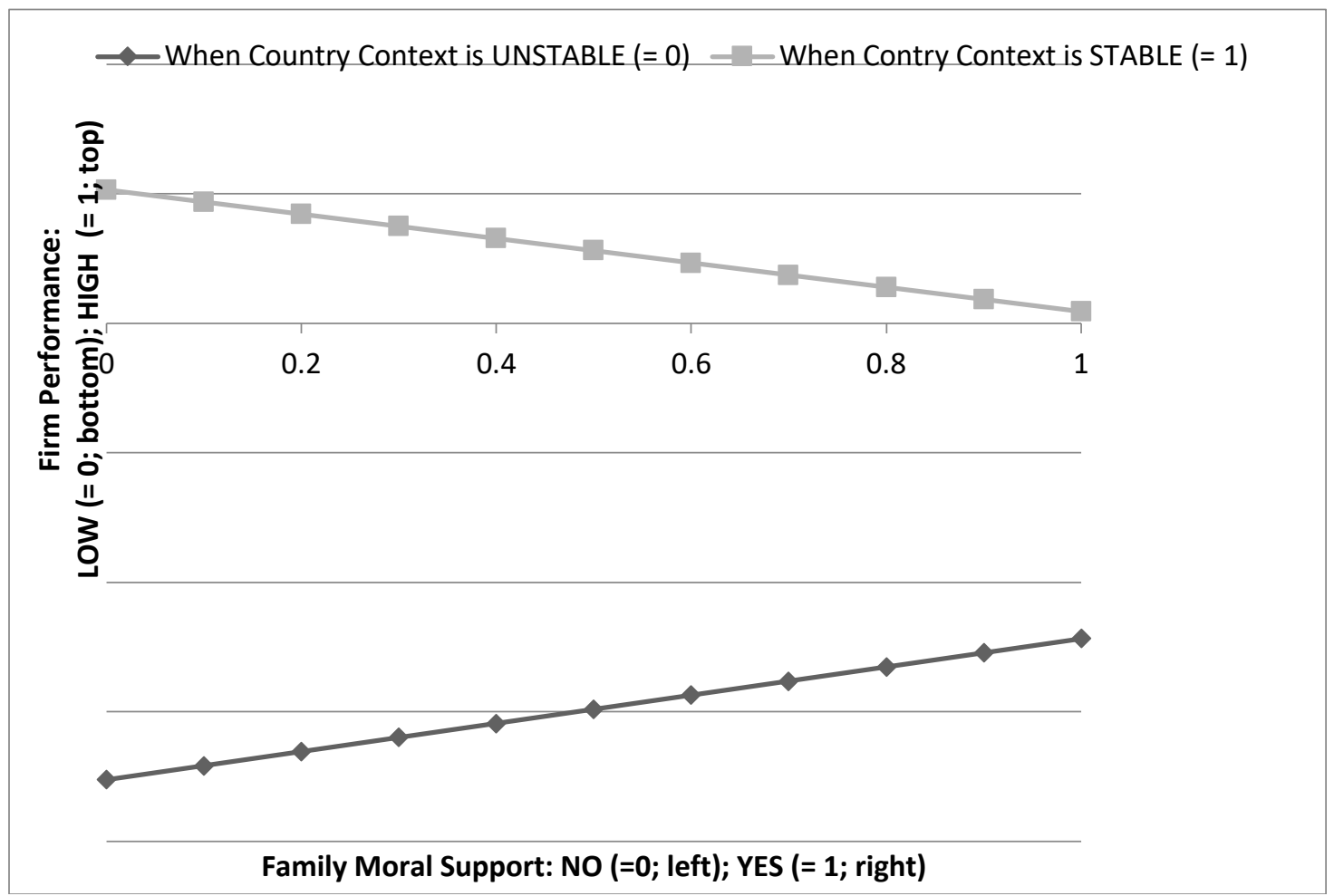

Fig. 2. Moderating effect of country political and social stability on the link between family moral support and firm performance. 
Table 1

Descriptive statistics for Jordan and Sudan combined (means and Pearson correlation coefficients)

\begin{tabular}{|c|c|c|c|c|c|c|c|c|c|c|}
\hline Variable & Mean & $\mathrm{N}$ & 1 & 2 & 3 & 4 & 5 & 6 & 7 & 8 \\
\hline $\begin{array}{l}\text { 1. Firm Performance } \\
\text { (PERF; Y) }\end{array}$ & 0.53 & 186 & 1 & & & & & & & \\
\hline $\begin{array}{l}\text { 2. Family Financial } \\
\left.\text { Support (FFS; } X_{1}\right)\end{array}$ & 0.16 & 193 & $0.178^{*}$ & 1 & & & & & & \\
\hline $\begin{array}{l}\text { 3. Family Moral } \\
\text { Support (FMS; } \mathrm{X}_{2} \text { ) }\end{array}$ & 0.68 & 191 & 0.084 & 0.018 & 1 & & & & & \\
\hline $\begin{array}{l}\text { 4. Country Stability } \\
\text { (STB) }\end{array}$ & 0.53 & 219 & $0.536^{* *}$ & $0.270^{* *}$ & 0.106 & 1 & & & & \\
\hline $\begin{array}{l}\text { 5. Entrepreneur's Age } \\
\text { (ENTR_AGE) }\end{array}$ & 0.49 & 201 & $-\overline{-}^{*} 206^{* *}$ & $-0.258^{* *}$ & -0.056 & $-{ }^{-} .355^{* *}$ & 1 & & & \\
\hline $\begin{array}{l}\text { 6. Firm's Age } \\
\text { (FIRM_AGE) }\end{array}$ & 0.56 & 202 & 0.021 & $-0.279^{* *}$ & -0.039 & $-0.185^{*}$ & $0.358^{* *}$ & 1 & & \\
\hline $\begin{array}{l}\text { 7. Firm's Size } \\
\text { (FIRM SIZE) }\end{array}$ & 0.48 & 199 & $0.233^{* *}$ & -0.082 & 0.129 & 0.101 & 0.031 & 0.098 & 1 & \\
\hline $\begin{array}{l}\text { 8. Family Business } \\
\text { Ownership (FBO) }\end{array}$ & 0.21 & 202 & $0.155^{*}$ & -0.009 & 0.081 & 0.130 & 0.038 & 0.003 & $0.306^{* *}$ & 1 \\
\hline $\begin{array}{l}\text { 9. Joining a network } \\
\text { (JOIN NETW) }\end{array}$ & 0.12 & 203 & $0.176^{*}$ & 0.009 & 0.091 & $0.199^{* *}$ & -0.042 & -0.021 & $0.201^{* *}$ & 0.029 \\
\hline rYXi & & & $0.178^{*}$ & 0.084 & 0.078 & & & & & \\
\hline rYXi.M & & & $0.171^{*}$ & 0.076 & 0.070 & & & & & \\
\hline $\mathrm{t}_{\alpha / 2, \mathrm{~N}-3}$ & & & 2.276 & 0.993 & 0.936 & & & & & \\
\hline
\end{tabular}


Table 2

Logistic (logit) regression results with the dependent variable Firm Performance (PERF).

\section{VARIABLES}

SAMPLE SIZES

Independent variables:

Family Financial Support (FFS)

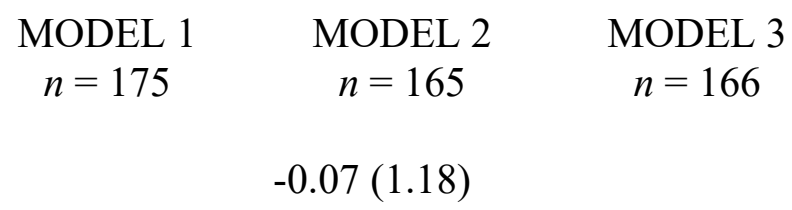

$-0.07(1.18)$

Family Moral Support (FMS)

Moderator variable:

Country Context (STB)

$2.65^{* * *}(0.48) \quad 4.55^{* * *}(1.06)$

Interaction terms:

FFS x STB

$1.47(1.42)$

FMS x STB

Control variables:

Entrepreneur's Age (ENTR_AGE)

Firm's Age (FIRM_AGE)

Firm's Size (FIRM_SIZE)

Family Business Ownership (FBO)

Intercept

Model $\chi^{2}$ (p-value)

Log likelihood

McFadden $\mathrm{R}^{2}$

$\begin{array}{lll}-0.96^{* * *}(0.36) & -0.26(0.45) & -0.25(0.46) \\ 0.36(0.36) & 0.89^{* *}(0.43) & 1.23^{* *}(0.52) \\ 1.00^{* * *}(0.34) & 0.66(0.42) & 1.40^{* * *}(0.35) \\ 0.52(0.45) & & 0.41(0.59) \\ -0.21(0.29) & -2.86^{* * *}(0.54) & -3.52^{* * *}(0.77) \\ 21.97^{* * *}(0.00) & 72.13^{* * *}(0.00) & 81.84^{* * *}(0.00) \\ -110.18 & -78.30 & -73.95 \\ 0.09 & 0.32 & 0.36\end{array}$


